\title{
Correction to: The Combined Contribution of Fear and Perceived Danger of COVID 19 and Metacognitions to Anxiety Levels during the COVID 19 Pandemic
}

\author{
Orkun Aydın ${ }^{1} \cdot$ Kuzeymen Balıkçı ${ }^{2}$ - Yasin Arslan ${ }^{1}$ • Pınar Ünal-Aydın ${ }^{1}$. \\ Ece Müezzin² $\cdot$ Marcantonio M. Spada ${ }^{3}$ (D)
}

Published online: 4 December 2021

(c) The Author(s) 2021

\section{Correction to: Journal of Rational-Emotive \& Cognitive-Behavior Therapy https://doi.org/10.1007/s10942-021-00429-9}

The original version of the article unfortunately contained a mistake in second and fifth authors' institutions. The correct institution of second author (Kuzeymen Balıkçı) is Faculty of Arts and Sciences, Department of Psychology, Final International University, Kyrenia, Turkish Republic of Northern Cyprus. The fifth author's (Ece Müezzin) correct institution is Faculty of Arts and Sciences, Department of Psychology, Final International University, Kyrenia, Turkish Republic of Northern Cyprus. This has been corrected with this erratum.

Open Access This article is licensed under a Creative Commons AttributionNonCommercial-NoDerivatives 4.0 International License, which permits any noncommercial use, sharing, distribution and reproduction in any medium or format, as long as you give appropriate credit to the original author(s) and the source, and provide a link to the Creative Commons license. You do not have permission under this license to share adapted material derived from this article or parts of it. The images or other third party material in this article are included in the article's Creative Commons license, unless indicated otherwise in a credit line to the material. If material is not included in the article's Creative Commons license and your intended use is

The original article can be found online at https://doi.org/10.1007/s10942-021-00429-9.

Marcantonio M. Spada

spadam@1sbu.ac.uk

1 Department of Psychology, Faculty of Arts and Social Sciences, International University of Sarajevo, Sarajevo, Bosnia and Herzegovina

2 Department of Psychology, Faculty of Arts and Sciences, Final International University, Kyrenia, Turkish Republic of Northern Cyprus

3 Division of Psychology, School of Applied Sciences, London South Bank University, London, UK 
not permitted by statutory regulation or exceeds the permitted use, you will need to obtain permission directly from the copyright holder. To view a copy of this license, visit http://creativecommons.org/licenses/by-nc-nd/4.0/.

Publisher's Note Springer Nature remains neutral with regard to jurisdictional claims in published maps and institutional affiliations. 